\title{
Reinterpreting the Indonesian Environmental Tortlaw in Addressing the Transboundary Haze Pollution
}

\author{
Shidarta \\ Faculty of Humanities, Universitas Bina Nusantara, Jakarta, Indonesia \\ shidarta@binus.edu
}

\begin{abstract}
Although the ASEAN Agreement on Transboundary Haze Pollution has been ratified by all members of ASEAN countries, in reality this agreement is not able to combat this transnational environmental problem and foster an environmentally suistanable community in Southeast Asia.The applicable agreement cannot be effective because it is not followed by any legal instrument that can deter the perpetrators of environmental crime.Therefore, private law instrument can be used by providing opportunities for community members to sue the haze polluter before a civil court. Unfortunately, Article 1365 of the Indonesian Civil Code (tortious liablity) has not been able to adequately address this need, so a breakthrough is needed.The author suggests using the legal doctrine of 'injuriasine damno'in order to interpret the meaning of Article 1365 more broadly, especially in relation to the element of loss.
\end{abstract}

Keywords: Pollution, Environmental, Civil Code

\section{INTRODUCTION}

Transbondary haze pollution is an annual problem involving several countries among the ASEAN community during the dry seasons. To address this issue, an agreement was established in 2002, known as the "ASEAN Agreement on Transboundary Haze Pollution" (ATHP).Nowadays, all ASEAN countries have accepted ATHP as international norms and respective national legal norms. Indonesia then endorsed this ATHP with Law No. 26 of 2014 on Ratification of AATHP and its instrument of ratification was deposited to the ASEAN Secretariat on 20 January 2015 so that under the terms of the agreement (Article 29), ATHP is effective and binding for Indonesia from 21March 2015.

Many believe ATHP has several weaknesses, partly because it has no coercive power to implement. ATHP does not prepare its enforcement instrumentsand leave it to the ratifying countries' own policies.It seems that the passion for not interfering in the domestic affairs of each country makes ATHP only a cooperative agreement to prevent and overcome haze pollution. Many scholars have critized this and condemned either the association's environmental negligence or its adherence to the principle of non-interference as the root of the organization's failure to prevent the recurrence of haze and fires [1].

Statistically, the extent of forest burning from year to year shows a fluctuating number. The most extensive forest destruction due to fire actually happened in 2015, the year when ATHP effectively applied to Indonesia. In that year, the area of burned forest was 261,060.44 hectares. In fact, opposed to one year before (2014), the forest area burned "only" 44,411.36 hectares. Indeed, there is a tendency, since 2016, the figure has decreased, covering an area of 
$14,604.84$ hectares and then to $11,127.49$ hectares in 2017 . The last figure is recorded by the Ministry of Environment until mid 2018 is 4,666.39 hectares. This figure is in fact still very high because it is close to the 2013 figure of 4,918.74 hectares [2].

The ineffectiveness of ATHP can also be brought about by the use of incorrect legal instruments. How to deal with wildfire in Indonesia so far has always been using the criminal law instrument. The use of such law proves to be ineffective because the initiatives to use this rely heavily on the state. Although the bush/forest burnersare given with criminal sanction, the affected citizens who have suffered from the deterioration of air quality, do not receive any compensation at all.Indonesia as a country that is often accused of being a polluter country also has difficulty in ensnaring these wildfires. The difficulty is not because of the obscurity of the perpetrator, since all hotspots can be monitored via satellite, so that the perpetrators will be easily identified. Indonesia's inability to act more firmly because of the concerns of local communities who take part in the practice of wildfire. The model of land clearing by burning the bush has long been considered a local wisdom. On one hand, the ban on land clearing by wildfire set forth in Law No. 18 of 2004 on Plantation juncto Law No 19 of 2004 concerning Forestry, while on the other hand there is permissibility given in the Law No. 32 of 2009 on Environmental Protection and Management, i.e. for local indigenous people with a maximum land area of two hectares.

This paper offers a breakthrough in the use of private law instruments, not criminal anymore. By using the private law instrument, the plaintiff can be Indonesian citizens or nonIndonesian citizens, but the defendants can be made selectively, for example, only big business actors owning land more than two hectares each. The proposed instrument still use the tortlaw as mentioned in Article 1365 of the Indonesian Civil Code and Law No. 32 of 2009. However, this private legal instrument requires reinterpretation, so that it can be used optimally to strive for the rights of citizens. The author of this paper argues that the legal instrument is actually sufficient to lay the groundwork for filing a lawsuit.

Article 1365 states, 'Every unlawful action, that brings damage to other person, obliges the person by whose fault causing such loss, to compensate such loss.' This paper is willing to look for the legal solution. The key to this answer is the courage of judges to overcome the weaknesses of legislation. The judges handling this lawsuit must dare to make a breakthrough in expanding the interpretation of Article 1365 of the Civil Code. For example, if there are hotspots in Jambi Province (Indonesia), and the haze from this place then quickly carried by the wind passing through Riau Province and then polluting Singapore and Malaysia, the question arises whether all residents of these regions have legal standing to file lawsuit against the burners, even if these areas are only passed by the haze without significantly disrupting air quality. Can judges in Indonesia provide an extension of meaning of tortious liability by reinterpreting the concepts of plaintiff's loss,beyond what has been known in Indonesian private law?

\section{LITERATURE REVIEW}

Among the efforts to anticipate the existence of a single economic community in the ASEAN region, it can be argued that the law harmonizing movement among its member states is the least performed. Judging from the characteristics of the family of the legal system that includes, ASEAN countries have an interesting diversity pattern because in it there are countries with civil law system (Indonesia), common law system (Malaysia, Singapore, Brunei Darussalam), socialist law system (Vietnam, Cambodia, Laos), and hybrid jurisdiction (the Philippines) [3], [4]. Although there has been a great deal of shifts to approach each other 
amongst the families of this legal system [5], it is inevitable that there is a distinct characteristic of each family of legal systems in understanding a legal concept. One of the interesting legal concepts to be used as the object of study is the concept of unlawful acts in the civil law aspect. In the common law system terminology, this unlawful act (onrechtmatigedaad) can be paired (but not identifiable) with tort [6], [7].

In the context of maintaining good interstate relations, usually these cross-border law cases are usually addressed through political and non-legal approaches. In fact, the parties concerned in these cases can be very broad. They are also civilians as an important subject in international private law. The right of these civilians to fight for their interests legally by using instruments that are acceptable to all families of the legal system is also a matter of concern as a form of ASEAN's anticipation of the unity of the economic community in the near future [8]. Departing from the motive, this paper will take a special topic on the concept of unlawful deeds and tort concepts and put them in the context of environmental laws that cross national borders. The elaboration of this concept of unlawful deed and tort will then arrive at a proposed use of the doctrine of injuriasine damno, a concept originally known in Roman law [9]. Unfortunately, this doctrine is not sufficiently developed in Indonesia, not even widely known in handling environmental law cases.

Unlawful acts, both in private law (tortious action) and in criminal law are two important concepts in legal discourse. In general, especially if it follows the mainstream of legal thinking in Indonesia, these two concepts have divergences in the direction of their interpretation. The action against the private law leads to widespread meaning (extension), namely by interpreting the law is not the same as legislation. Thus, the meaning of the term 'onrechtmatig'(against the law) is different with that of 'onwetmatig' (against the legislation). The historical momentum of this expansion took place after the verdict of HogeRaad der Nederlanden on 31 January 1919, in the case of Lindenbaum versus Cohen. Another case with the act against the law in the criminal field that actually leads to a narrower meaning (restrictive), which is more directed to the nature of the law against formal (formelewederrechtelijkheid). The so-called law generally refers to the provisions of positive norms in the existing, written, and applicable criminal legislation system prior to the act being committed. Violation of this requirement constitutes a serious violation of the principle of legality.

If there is a divergence in the two fields of law, then what about unlawful acts in the field of environmental law? It is interesting to ask because the realm of environmental law can not be fully incorporated into civil and criminal law criteria. By quoting Drupsteen, KoesnadiHardjasoemantri says environmental law (millieurecht) is a law related to the natural environment (natuurlijkmillieu) in the widest sense. Its scope is related to and determined by the scope of environmental management. Thus, environmental law is a juridical instrumentarium for environmental management. Considering that environmental management is conducted primarily by the government, the environmental law is largely composed of government law (bestuursrecht). In this paper, unlawful acts in the realm of environmental law are given the nomenclature of 'action against environmental law' [6].

The basis of the action against the civil law is Article 1365 of the Indonesian Civil Code, which historically has a similar meaning to Article 1401 BurgerlijkWetboek (old) Netherlands. According to L.C. Hoffmann, from the sound of Article 1401 this can be derived at least four elements, namely: (1) there must be doing the deed, (2) the act must be against the law, (3) the act must cause harm to others, and (4) it is because of a mistake that can be harmed to him. Mariam DarusBadrulzaman specifies this unlawful act into five elements: (1) there must be action (positive or negative), (2) the act must be against the law, (3) there is a loss, (4) there is a relationship between acts against the law with loss, and (5) there is a mistake [7]. 
Since the arrest of the Lindenbaum-Cohen case of January 31, 1919, the interpretation of unlawful acts in the field of private law can at least be related to four things: the act must: (1) violate the rights of others; (2) contrary to the offender's legal obligations, or; (3) contrary to good morality, or; (4) contrary to the propriety which is found in the society of the self or the goods of others. The significance of the verdict after the previous rulings tends to narrow the meaning of "law" as well as the meaning of "law", for example in the decision of the Singer sewing machine (1905) and the plumbing case of Zutphen (1910) [8]. If Article 1365 isapplied into environmental law, there are some notes should be considered.

First, the notion of violating the rights of others here covers a large area of denotation. The person does not have to be a subject who resides in a location directly affected by pollution or environmental destruction. This person can be made up of those who are ideally disadvantaged, for example, non-governmental organizations in the environmental field. Second, the notion of contradicting the legal obligations of the offender is a duty under the law. The word "law" here includes laws in the material sense, including criminal legislation. This means a person committing a criminal offense for stealing or cheating, in addition to being criminally prosecuted, is also possible because of the harm he incurred to be sued in a private case.Third, the notion of contradicting good morality and propriety can be regarded as an important extension of the interpretation of unlawful acts. Both of these limits can indeed change over time and differ from one community to another. There are opinions that say that acts contrary to propriety are in itself contrary to decency. What is known as "contrary to propriety" is if: (1) the act is very harmful to others without a worthy interest, and (2) it is useless or harmful to others.

There is an interesting matter to distinguish between the provisions of Article 1365 Civil Code and Article 1366 Civil Code. Redactionally, the provisions of Article 1365 use the words "for the false" (schuld) which are different from the sound of Article 1366 which reads "due to negligence or indifference" (nalatigheid; onvoorzichtigheid). The word "against the law" implies both active and passive action. L.E.H. Ruttensays that if Article 1365 of the Criminal Code emphasizes active action, then Article 1366 emphasizes the aspect of omission (do not do) [9].These two provisions are supposedly inspired by the distinctions commonly held in criminal law, namely deliberate and negligent. Thus, all acts caused by intent or neglect or inadvertence can be categorized as unlawful, as long as the act is wrong (breaking the law in a broad sense), and therefore the perpetrator deserves to be given the burden of compensation.

The concept of unlawful acts within the scope of law (civil) within the family of the civil law system has similarities and differences with the known tort concept in the common law system family [10]. Eventhough to some extent there are several conceptual differences, the rights of civilians to defend their interests are not constrained simply because of differences in the legal system.

Among the elements of unlawful deeds and tort that are mentioned above, it seems that the loss aspect becomes a serious enough matter to prove. The impact of large-scale material losses can indeed be calculated, such as public health, bio-diversity, tourism, air transport, and agricultural production [10]. However, for most civilians these enormous material losses often have to be discouraged because they will rely on initiation of their lawsuit to the state authorities.

In Indonesian environmental law, there is indeed an opportunity for non-governmental organizations (NGOs) to file claims on behalf of the interests of the community, but this has not produced much results. According to D.S. Jones, the likelihood of the NGO Walhi succeeding in its legal action may be slim since over the last 30 years it has won only one 
legal action against environmental offenders [10]. The second option is to give all people the chance to carry out class action.In the context of this second choice, all affected residents can carry out class action suits together. Not only is it open to Indonesian citizens, but also to those of neighboring countries.

Is it for instance unlikely that ordinary civilians are suing on their losses because of the decrease in the quality of air they breathe in during the smog that struck their respective countries? In the context of the use of the concept of unlawful acts, known in the civil law system as well as common law, there is actually a gap that can be offered as discourse. Through these legal loopholes it is hoped that the ordinary civilian difficulties to file civil suits can be overcome, regardless of their burden to prove that there is an element of loss with all the complexities of the calculations.

A.J. Pannett states that in principle the law shall not impose any obligation of compensation for any form of offense [11]. The types of damages called damnum sine injuria are exemplary examples, i.e. if the loss is caused by an offense committed because the offender is carrying out the law order. This means that, even if there is a loss, if the perpetrator acts because of carrying out the law, he is not obliged to compensate for that loss. On the contrary, it turns out there is also the doctrine of injuria sine damno, which says that although there is no loss, the perpetrator remains obliged to compensate. Pannett calls this example of the application of the latter doctrine the act of entering another's property (trespass). Black's Law Dictionary refers to this doctrine with the injury of absquedamno, which he means as 'injury without damage' [12].

This doctrine is commonly applied in civil lawsuits, but that does not mean it can not be applied to causes tending to public dimension, such as humiliation, fraud, and misdemeanor. Even in the case of Ashby versus White (1703-1704) this doctrine was used by Judge Lord Holt in his dissenting opinion when dealing with the constitutional rights of the plaintiff who were "disadvantaged" for being barred from voting. Holt wrote in the verdict as follows:

"If the plaintiff has a right, he must of necessity have a means to vindicate and maintain it, and a remedy if he is injured in the exercise or enjoyment of it, and, indeed it is a vain thing to imagine a right without a remedy; for want of right and want of remedy are reciprocal... And I am of the opinion that this action on the case is a proper action. My brother Powell indeed thinks that an action on the case is not maintainable, because there is no hurt or damage to the plaintiff, but surely every injury imports a damage, though it does not cost the party one farthing, and it is impossible to prove the contrary; for a damage is not merely pecuniary but an injury imports a damage, when a man is thereby hindered of his rights. To allow this action will make public officers more careful to observe the constitution of cities and boroughs, and not to be so partial as they commonly are in all elections, which is indeed a great and growing mischief, and tends to the prejudice of the peace of the nation" [13].

\section{METHOD}

This paper is organised with a conceptual approach in which such an approach discusses themain concept of unlawful act or tort law that are closely related to interpretation as a method in the judicial law-making process. At the end of this paper, the author offers the conclusion as the answer of the problem statement and the result of an effective literature review. 


\section{RESULT and DISCUSSION}

The above doctrines are interesting to examine in the context of the Law on Environmental Management (the old Law No. 23 of 1997, before being replaced by Law No. 32 of 2009 on Environmental Protection and Management, hereinaferabbreviated as UUPPLH). For the first doctrine, damnun sine injuria, can be appointed Article 35 paragraph (2) of UUPLH. In this paragraph, there are several reasons that exempt perpetrators of pollution and/or environmental damage from the obligation to pay compensation. The reasons are if there is a natural disaster or war, circumstances are forced beyond human capabilities, and third-party actions that cause environmental pollution and/or damage. The meaning of this third party according to the sound of explanation of this paragraph is a fellow business actor or government. The provisions of Article 35 paragraph (2) are in fact deviating from the provisions of paragraph (1) which are equally in paragraphs entitled "Absolute Responsibility" (in the new Law, set forth in Article 88). The principle of absolute liability (strict liability) is defined according to the explanation of those articles as "... the element of error does not need to be proven by the plaintiff as the basis for the payment of compensation." It further states that the provisions of this paragraph are lexspecialis in the lawsuit of unlawful conduct in general. The amount of compensation that can be imposed on polluters or environmentalists can be set to some extent.

The provisions of Article 35 paragraph (1) of UUPLH or Article 88 of UUPPLH is actually an important spirit that shows the characteristics of actions against environmental law. Black's Law Dictionary defines strict liability as liability without fault [12]. This concept is actually better known in product responsibility and consumer protection. With the adoption of this principle of responsibility in UUPLH it must logically be understood that the element of error in the act against the law of the practical environment is no longer possible to be interpreted restrictively.

Koesnadi Hardjasoemantri acknowledges that Article 35 UUPLH (or Article 88 UUPPLH) is in fact not applicable to all activities, but must be applied selectively. He declared that this article was originally accommodated in Article 21 of the Environmental Law (formerly), which says: "In certain activities involving certain types of resources, responsibility arises in absolute terms for the destroyers and/or polluters at the time of the destruction and/or pollution of the environment which arrangements are regulated in the relevant legislation." Lawmakers recognize that the principle of absolute responsibility by reversing the burden of proof is not only applicable, so that the implementation is done in stages in accordance with the development needs. However, citing Rüdiger Lummert's view, Koesnadi realizes that along with the rapid increase of industrialization, the risks and complexity of causal relationships also increase. Therefore legal theory has abandoned the concept of 'mistake' and turned to the concept of 'risk' [14].

What is the meaning of the review of errors and risks in the context of unlawful acts? According to R. Setiawan, the word 'mistake' in Article 1365 of the Civil Code refers to the responsibility for an act contrary to law. The word "mistake" is thus often used as a synonym for unlawful acts. Meanwhile, 'risk' is used as opposed to error, to show accountability events without error [6].

The principle of absolute responsibility is clearly not adhered to in Article 1365 of the Civil Code. It is understandable that the judges who handled the lawsuit against the law on the basis of the lawsuit using this article, finally stuck to no longer pay attention to the provisions of the law in the field of environment. For example, in the case of a court in Indonesia, namely the decision of South Jakarta District Court No. 548/Pdt.G/2007/PN.JAK.SEL (lawsuit against 
PT Newmont Minahasa Raya in a pollution case in Buyat Bay). In fact, any errors that have been proven, for example violating the permit, in environmental law are risky actions to invite losses in the future. At this point there is an entrance to the doctrine of injuriasine damno [15].

Violation of permission in the doctrine of injuria sine damno in the context of narrowly cross-border environmental cases can be interpreted as a pass through private spaces. The entry of harmful substances in the air content that residents inhaled in private spaces is an analogy of trespassing. Thus, where there is a lawsuit from civilians, without limitation to the territory of the state, may be accommodated within the legal system in Indonesia as well as in the country concerned, by adopting the principle of equality between this unlawful act and tort.

Through the doctrine of injuria sine damno, the aspect of error with the absence of 'permission' for the entry of pollutant substances into private spaces certainly will not cause any difficulties in the proof. The case of entry due to natural factors (wind gusts) and not because of the intentional factor of the perpetrator, should also not be a problem because both the lawless act (onrechtmatigedaad) version of the civil law system and tort the common law version does not require intentional motives always exist. With the frequency of events that continue to occur, it can also be said that the aspect of causality as one element of the act against the law and tort can be estimated.

This doctrine of injuria sine damno gives its own color when it must be presented with or without the concept of strict liability. In the concept of strict liability as adopted in the UUPPLH, the existence of whether or not the error is no longer an element, but the real losses remain to be demonstrated by the plaintiff. This is important because real losses will be used as the basis for calculating the feasibility of the claim. If the doctrine of injuria sine damno is used as a combination of the concept of strict liability under UUPPLH (Indonesia), then the dimensions of this loss also need not be rigidly demonstrated by the plaintiff. Therefore, the procedure for calculating the suitability of the plaintiff's suit is not necessarily real (physical). In environmental law, the breakthrough of the procedure of calculating the amount of demands for compensation is already very developed, even reaching the calculation of futuristic (across generations). That is, from the aspect of determining the amount of compensation claims, the use of this doctrine also need not be contradicted by the existence of the concept of liability strict liability in UUPPLH.

\section{CONCLUSION}

The act of extending the meaning of Article 1365 of Indonesian Civil Code is a breakthrough to grant citizens the right to sue transboudary haze polluters. The task for this expansion can be initiated by judges in Indonesia. Judges are those who have the task to reinterpret the Indonesian tortlaws to address this apparent need, amid the weakness of law enforcement from ATHP.Article 1365 has so far been interpreted in a limited way with the obligation to contain real losses, while in the case of transboundary haze pollution, this element of loss is not always easy to determine.

Article 1365 of the Civil Code is a legal basis that can be used as a basis for a lawsuit against the perpetrators of transbondary haze pollution. These cases are related to the environment, so the strict liability concept also applies, in the sense that the error element is irrelevant to prove. The problem lies in the aspect of loss. By using the injuria sine damnodoctrine, the loss factor eventually becomes irrelevant to question.

Haze arising from the burning of bush / forest which is then carried by the wind into an open space, even if only passing, is a form of violation as well, without having to be burdened with evidence of losses with the possibility of complicated calculations. Thus, Singaporeans 
and Malaysians directly affected by haze pollution can sue together with other Indonesian citizens. The author suggests that the lawsuit should be filed in the class action procedures with cross-country and cross-generation class members.

\section{REFERENCES}

[1] P. Nguitragool, Environmental cooperation in Southeast Asia: ASEAN'S regime for transboundary haze pollution. New York: Routledge, 2011.

[2] Direktorat Pengendalian Kebakaran Hutan dan Lahan, "Rekapitulasi luas kebakaran hutan dan lahan (Ha) per provinsi di Indonesia tahun 2013-2018," 2018.

[3] P. De Cruz, Comparative law in achanging world. London: Cavendish Publishing.

[4] K. Zweigert and H. Kötz, An introduction to comparative law. Oxford: Clarendon Press, 1987.

[5] P. Glenn, "Reconciling Legal Traditions: Sustainable Diversity in Law," in Legal Traditions of the World, Oxford: Oxford University Press, 2010, pp. 361-386.

[6] R. Setiawan, Tinjauan elementer perbuatan melanggar hukum. Bandung: Binacipta, 1991.

[7] R. Agustina, Perbuatan Melawan Hukum. Jakarta: Program Pascasarjana Fakultas Hukum Universitas Indonesia, 2003.

[8] M. Natalegawa, Does ASEAN matter? A view from within. Singapore: ISEAS Publishing, 2018.

[9] C. Assers, Pedoman Untuk Pengajian Hukum Perdata Belanda. Jakarta: Dian Rakyat, 1991.

[10] A. J. Pannett, Law of torts. London: Pitman Publishing, 1992.

[11] D. S. Jones, "ASEAN and transboundary haze pollution in Southeast Asia," Asia Eur. J., vol. 4, no. 3, pp. 431-446, Sep. 2006.

[12] H. C. Black, Black's law dictionary. St. Paul: West Publishing, 1990.

[13] C. Stephenson, Sources of English constitutional history: A selection of documents from AD 600 to the present. New York: Harper \& Brothers, 2008.

[14] K. Hardjasoemantri, Hukum Tata Lingkungan. Yogyakarta: Gadjah Mada University Press, 1999.

[15] Shidarta, "Perbuatan melawan hukum lingkungan: Penafsiran ekstensif dan doktrin injuria sine damno," J. Yudisial, vol. 3, no. 1, pp. 65-84, 2010. 